\title{
Microclimate in silvipastoral systems with eucalyptus in rank with different heights
}

\author{
Wander de Souza ${ }^{1}$, Orlando Rus Barbosa ${ }^{2}$, Jair de Araújo Marques ${ }^{3}$, Marco Aurélio Teixeira \\ Costa $^{2}$, Eliane Gasparino ${ }^{2}$, Erni Limberger ${ }^{1}$
}

1 Instituto Paranaense de Assistência Técnica e Extensão Rural - Emater.

2 Universidade Estadual de Maringá - UEM.

${ }^{3}$ Universidade Federal do Recôncavo da Bahia - UFRB.

ABSTRACT - The aim of this work was to verify if the presence of trees and its height in formed silvipastoral systems with eucalyptus planted in rank can modify the microclimate and improve the environment for bovine raising during the day in summer. It was evaluated the microclimate of the environment in formed silvipastoral systems in rank of eucalyptus with $8 \mathrm{~m}, 18 \mathrm{~m}$ and 28 meters of height, compared to a system no shade in the summer. The experimental design was a split plot with six hour time in sub parcels. The systems are made up of parcels and the months as block in four replications and the interaction hour $\times$ system. The air temperature, black globe temperature, relative humidity and wind speed were observed to create the following indexes for thermal comfort: temperature-humidity index; black globe-humidity index; heat load index and the radiant thermal load. Excepted for the relative humidity, there was interaction for time $\times$ system for all variables and indexes. Interaction occurred for: air temperature at 10 a.m. and 6 p.m.; wind speed from 8 a.m. to 4 p.m.; temperature humidity index at 10 a.m. and 12 p.m.; black globe temperature, black globe humidity index, heat load index, and radiant thermal load at all the hours. During the summer, the system with shade of $28 \mathrm{~m}$ trees had the lowest average of black globe temperature; wind speed; black globe humidity index; radiant thermal load index; and heat load index. There was a reduction of wind speed average in systems $8 \mathrm{~m}, 18 \mathrm{~m}$ and $28 \mathrm{~m}$ trees in, respectively, 20.7; 50.0 and $48.0 \%$ in relation to no shade system; however it was not proportional to the height, with influence of the rank porosity and pantries height. Nevertheless, for radiant thermal load index the reduction was proportional to the height of the trees with 10.24; 12.49 and 20.76\%, respectively, for $8 \mathrm{~m}, 18 \mathrm{~m}$ and 28 meters of height. There was a reduction of the thermal stress in the environment due to the presence of trees, being the heat load index thermal the index that better demonstrated the effect, despite of not being proportional to the rank height.

Key Words: ambient, heat stress, index, shade, thermal comfort, trees

\section{Microclima em sistemas silvipastoris com eucalipto em renques com diferentes alturas}

RESUMO - Objetivou-se verificar se a presença de árvores e sua altura em sistemas silvipastoris formados com eucalipto plantados em renques podem alterar o microclima e melhorar o ambiente para a criação de bovinos durante o dia no verão. Avaliou-se o microclima do ambiente em um sistema sem árvores e em três sistemas silvipastoris com renques de eucalipto com 8, 18 e 28 metros de altura no verão. O delineamento experimental foi em parcelas subdivididas, com seis horários nas subparcelas, tendo nos sistemas as parcelas e os meses como bloco em quatro repetições e a interação sistema $\times$ horário. A temperatura do ar, a temperatura do globo, a umidade relativa e a velocidade do vento foram observadas para a formação dos seguintes índices de conforto térmico: índice de temperatura e umidade (ITU); índice de temperatura do globo-umidade (ITGU); índice de carga térmica e carga térmica radiante. Com exceção da umidade relativa, houve interação sistema $\times$ horário para todas as variáveis e índices. Ocorreu interação para: temperatura do ar às $10 \mathrm{~h}$ e às $18 \mathrm{~h}$; velocidade do vento das $8 \mathrm{~h}$ às $16 \mathrm{~h}$; ITU às 10 h e 12 h; temperatura do globo, ITGU, índice de carga térmica e carga térmica radiante em todos horários. No verão, o sistema com sombra com árvores de $28 \mathrm{~m}$ foi o que promoveu as menores médias de temperatura do globo, velocidade do vento, ITGU, carga térmica radiante e índice de carga térmica. A velocidade do vento média nos sistemas com árvores de 8 m, 18 m e 28 m diminuiu, respectivamente, 20,7; 50,0 e 48,0\% em relação ao sistema sem sombra, porém essa redução não foi proporcional à altura e teve influência da porosidade dos renques e da altura das copas. Para a carga térmica radiante, a redução foi proporcional à altura das árvores, com 10,24; 12,49 e 20,76\%, respectivamente, para os sistemas com árvores de $8 \mathrm{~m}, 18 \mathrm{~m}$ e $28 \mathrm{~m}$. O estresse térmico ambiente reduziu com a presença de árvores e o índice de carga térmica foi o que melhor representou esse efeito, todavia essa redução no estresse térmico não foi proporcional à altura dos renques.

Palavras-chave: ambiente, árvores, conforto térmico, estresse térmico, índices, sombra 


\section{Introduction}

Limitations to animal production in tropical regions may be caused by the four main environmental stressful climatic elements: air temperature, air humidity, solar radiation and wind speed (Barbosa \& Silva, 1995). You can control these factors at indoors and inside of buildings by keeping the microclimatic conditions within, or very close, to the limits of the so-called "comfort zones". At outdoors, the microclimate can also be improved by planting trees and shrubs, allowing higher levels of comfort (Detzel, 1992). Bacarri Jr. (2001) found that shading may reduce from 30 to $50 \%$ the heat load on animals.

The thermal environment, both shaded area and nonshaded area, is evaluated according to the thermal comfort indices. Usually, these indices consider the environmental parameters of temperature, humidity, wind and radiation, and each parameter has a certain weight within the index according to their relative importance to the animal (Sampaio et al., 2004). The thermal comfort indices commonly used are the following: temperature-humidity index developed by Thom (1958); black globe-humidity index, proposed by Buffington et al. (1981); heat load index, developed by Gaughan et al. (2002) and used by Silva et al. (2007); radiant heat load, proposed by Esmay (1979).

Moura \& Nããs (1993) report that thermal comfort indices are important for farmers because they can, through a single value, quantify the thermal stress to which the animal is subjected to at given time and place, according to the existing weather conditions.

Farmers searching for more efficient production systems have introduced silvopastoral systems capable of circumventing problems of adverse soil and climate conditions, structured consortium of annual crops, tree species of rapid growth, pasture and animals (Menarim Filho, 2007).

The objective of this study was to evaluate if the presence of trees and their height in silvopastoral systems made up by eucalyptus planted in ranks can change the microclimate and improve the environment for the cattle during the day in summer, in the northwest of Paraná State.

\section{Material and Methods}

The experiment was conducted in northwestern Paraná, near the town of Paranavaí $\left(23^{\circ} 04^{\prime}\right.$ south latitude and $52^{\circ} 27^{\prime} \mathrm{W}$ ), characterized by a Cfa humid subtropical mesothermal climate, according to the classification of Köppen (Iapar, 1994). Four systems were evaluated: the first without a shade; the second with silvopastoral systems, with two years of implementation and trees with average height of $8 \mathrm{~m}$; the third with six years of implementation and trees with average height of $18 \mathrm{~m}$; the fourth with silvopastoral systems, with 16 years of deployment and tree average height of $28 \mathrm{~m}$. In all systems with shade, trees (Eucalyptus spp) were arranged in ranks, following the ground level, with average density of 160 trees per hectare, $2.5 \mathrm{~m}$ between trees, 20 to $35 \mathrm{~m}$ spacing. In silvopastoral systems, the trees did not have their branches cut during their development.

Following the methodology proposed by Silva et al. (1998), selection of data collection point in each tree system was performed in the selected location with similar characteristics to the spacing between rank and trees and the sequence of the ranks.

The wind speed, air temperature, dew point temperature, relative humidity of the air, black globe temperature and partial pressure of steam were recorded. For systems with shade, it was collected the data in the geometric center of the shade (mobile site) and between the ranks (fixed location) and for the system without shade, the data were collected at a fixed location.

Through pocket weather station $\left(\operatorname{THAL} 300^{\circledR}\right)$, air temperature and relative humidity were collected in instantaneous reading and while the variable speed wind was obtained by averaging the maximum and minimum values occurred in ten seconds of reading to be a variable of great variation. The temperature of the globe was obtained by using a black globe with plastic ball with $15 \mathrm{~cm}$ diameter and alcohol thermometer. The temperature of the dew point and partial pressure of steam were obtained using psychometric equations

In order to assess the environment, the equipment was placed at $1.60 \mathrm{~m}$ above the ground, simulating the height of the dorsum of the animals (Silva et al., 1995). They were placed horizontally at an average distance of $0.5 \mathrm{~m}$ from the trunk of the tree or the geometric center of the shade and displaced according to the inclination of the sun, and consequently to the movement of the shade.

A study of the displacement of the shade throughout the day was made so to obtain a location for setting the equipment to read the data, which were adjusted to each collection. The data collections started when the sky was with no cloud cover and was cancelled in the occurrence of many clouds that intercept solar radiation.

The experiment was carried out from December 2006 to March 2007, totalizing 25 days of observation. In the days of evaluation, data were collected during the hours of 8 a.m., 10 a.m., 12 p.m., 2 p.m., 4 p.m. and 6 p.m., simultaneously in all treatments. 
For data interpretation the following thermal comfort indices were used :

a) Temperature-humidity index (THI), proposed by Thom (1958):

$\mathrm{THI}=\mathrm{TA}+0,36 \mathrm{TDP}+41,5$

where $\mathrm{TA}=$ air temperature $\left({ }^{\circ} \mathrm{C}\right)$; $\mathrm{TDP}=$ dew point temperature $\left({ }^{\circ} \mathrm{C}\right)$.

b) Black globe-humidity index (BGHI), proposed by Buffington et al. (1981):

$\mathrm{BGHI}=\mathrm{BT}+0,36 \mathrm{TDP}+41,5$

where: $\mathrm{BT}=$ black globe temperature $\left({ }^{\circ} \mathrm{C}\right)$; $\mathrm{TDP}=$ temperature dew point $\left({ }^{\circ} \mathrm{C}\right)$

c) Thermal load index (HLI), developed by Gaughan et al. (2002)

HLI $=33,2+0,2 \mathrm{RH}+1,2 \mathrm{BT}-(0,82 \mathrm{WSPD})^{0.1}-\log (0,4$ $\left.\mathrm{WSPD}^{2}+0,0001\right)$

where: $\mathrm{BT}=$ black globe temperature $\left({ }^{\circ} \mathrm{C}\right)$; $\mathrm{RH}=$ relative humidity, decimal; WSPD = wind speed, in m/s.

d) Radiant thermal load (RTL), proposed by Esmay et al. (1979):

$\mathrm{RTL}=\sigma \mathrm{T}_{\mathrm{rm}}{ }^{4}, \mathrm{~W} / \mathrm{m}^{2}$

where: $\sigma=$ constant of Stefan-Boltzmann $\left(5,67 \times 10^{-8}\right.$, $\left.\mathrm{W} \cdot \mathrm{m}^{-2} \mathrm{~K}^{-4}\right) ; \mathrm{T}_{\mathrm{rm}}=$ mean radiant temperature $\left(\mathrm{T}_{\mathrm{rm}}=100\right.$ $\left\{2,51 \mathrm{WSPD}^{0,5}((\mathrm{BT}+273)-(\mathrm{TA}+273)+((\mathrm{BT}+273) /\right.$ $\left.\left.\left.100)^{4}\right)\right\}^{0,25}\right)\left({ }^{\circ} \mathrm{K}\right)$; where: $\mathrm{TA}=$ air temperature $\left({ }^{\circ} \mathrm{C}\right)$; $\mathrm{BT}=$ black globe temperature $\left({ }^{\circ} \mathrm{C}\right)$; WSPD $=$ wind speed, in $\mathrm{m} / \mathrm{s}$.

The temperature is indicated by the globe, which is placed in a space that would be occupied by an animal, to estimate the combined effects of radiant heat coming from the environment in every possible direction, air temperature and wind speed, giving a thermal comfort measure provided by the environment (Silva, 2000).

The design used was a split plot, with the heights of trees in the plots and hours of collections in the subplots. The main effect was compared to the error (e) and the times and the interaction time and time with the error (d), using the month as a block, with the following model: $\mathrm{Y}_{\mathrm{ijk}}=\mathrm{u}+$ $\mathrm{A}_{\mathrm{i}}+\mathrm{B}_{\mathrm{j}}+\mathrm{e}_{\mathrm{ij}}+\mathrm{H}_{\mathrm{k}}+\mathrm{AH}_{\mathrm{ik}}+\mathrm{d}_{\mathrm{ijk}}$, where: $\mathrm{u}=$ constant associated with all observations; $A_{i}=$ effect of heights $i$, $\mathrm{i}=1,2$, 3 e 4; $B_{j}=$ effect of block (replicates); $e_{i j}=$ random error associated with the parcel; $\mathrm{H}_{\mathrm{k}}=$ effect of time of measurement $\mathrm{k}, \mathrm{k}=1,2,3,4,5,6 ; \mathrm{AH}_{\mathrm{ik}}=$ effect the interaction of height $\mathrm{i}$ and time $\mathrm{k} ; \mathrm{d}_{\mathrm{ijk}}=$ random error associated with the subplot.

The average of the observations of the hours for each month (block) of environmental variables and indices were subjected to analysis of variance and means compared by Tukey test at $5 \%$ probability using test at $5 \%$ probability using Sisvar, the statistical computer (Ferreira, 2000).
The regressions were selected by $F$ test $(\mathrm{p}<0.05)$. The points of maximum and minimum cubic regressions and the maximum or minimum of the quadratic were calculated with the help of the Winplot (Parris, 2008).

\section{Results and Discussion}

During the summer in the regions adjacent to the $23.5^{\circ}$ parallels of 23.5 degrees, the solar radiation is more intense in the summer solstice, when the sun is at right angles on the line of the Tropic (Silva, 2000) of Capricorn nearby the observed systems $\left(23^{\circ}\right)$.

The average values of air temperature showed interaction $(\mathrm{P}<0.05)$ time $\times$ system. At 10 a.m. and 6 p.m., the systems differ $(\mathrm{P}<0.05)$, but there were no differences $(\mathrm{P}>0.05)$ at the other hours. (Figure 1). The lowest mean air temperature (Figure 1) was obtained at 8 a.m., but there was no difference between systems $(\mathrm{P}>0.05)$. According to Silva (2000), the protection afforded by the shade is a barrier to radiant heat, and not the heat itself, since this protection does not change the air temperature. According to the results at 10 a.m., the air temperature was higher in the system without shade (mean $30.2^{\circ} \mathrm{C}$ ) and did not differ $(\mathrm{P}>0.05)$ in $18 \mathrm{~m}$ tree system $\left(29.7^{\circ} \mathrm{C}\right)$, but significantly different $(\mathrm{P}<0.05)$ to $8 \mathrm{~m}$ tree systems $\left(28.5^{\circ} \mathrm{C}\right)$ and the $28 \mathrm{~m}$ tall trees system $\left(28.9^{\circ} \mathrm{C}\right)$ that did not differ $(\mathrm{P}>0.05)$. At 6 p.m., the air temperature was higher $(\mathrm{P}<0.05)$ in systems without shade $\left(31.6^{\circ} \mathrm{C}\right)$ and in $8 \mathrm{~m}$ tree system $\left(32.2^{\circ} \mathrm{C}\right)$, which were the same, and differed $(\mathrm{P}<0.05)$ from the values obtained in the $18 \mathrm{~m}$ tree systems $\left(30.3^{\circ} \mathrm{C}\right)$ and $28 \mathrm{~m}$ trees $\left(31.3^{\circ} \mathrm{C}\right)$ that did not differ $(\mathrm{P}>0.05)$ between them, while the $28 \mathrm{~m}$ tree system did not differ $(\mathrm{P}>0.05)$ from systems without shade and shade of $8 \mathrm{~m}$ trees. The presence of trees may explain the difference in air temperature between the systems during the hours of 10 a.m. and 6 p.m., by the elevation of the angle of the sun, where the projection of the shade of the trees between the ranks was a larger area, and also after the 4 p.m., intercepting the solar radiation, by faster retarding the increase or decrease of the temperature of the air and protecting the environment from direct solar radiation. Average temperatures in the different systems between 12 p.m. and 6 p.m. ranged from $30.3^{\circ} \mathrm{C}$ to $33.7^{\circ} \mathrm{C}$ and are above the upper critical temperature outside the thermoneutral zone for cattle of european origin $\left(25\right.$ to $\left.27^{\circ} \mathrm{C}\right)$ and close to the limit for the indians (TCS $\geq 35^{\circ} \mathrm{C}$ ) (Silva, 2000), proving to be limiting for the welfare of animals. However, the reading of temperature for different system was observed above $35^{\circ} \mathrm{C}$; systems without shade, $8 \mathrm{~m}$ tree system, $18 \mathrm{~m}$ tree system and $28 \mathrm{~m}$ tree system were respectively, 12.8, 
$12.5,6.1$ and $7.5 \%$ of reading above $35^{\circ} \mathrm{C}$ higher than the upper critical temperature for indian cattle.

In all systems, the air temperature (Figure 1) gradually increased during the day, with higher average in the afternoon, because of irradiation, since the environment absorbing the energy of the direct radiation from the sun heats and relays this stored energy increasing the temperature of the environment (Silva, 2000).

The regressions of time on the air temperature (Figure 1) showed a quadratic effect $(\mathrm{P}<0.05)$ for all systems. For the regressions of the systems, the points of maximum air temperature predicted to range from $8 \mathrm{a} . \mathrm{m}$. to $6 \mathrm{p} . \mathrm{m}$. occurred in the system without a shade at $2 \mathrm{~h} 40 \mathrm{p} . \mathrm{m} .\left(33.5^{\circ} \mathrm{C}\right)$, in the $8 \mathrm{~m}$ tree system at $3 \mathrm{~h} 44$ p.m. $\left(33.2^{\circ} \mathrm{C}\right)$; in the $18 \mathrm{~m}$ tree system at $2 \mathrm{~h} 19$ p.m. $\left(32.9^{\circ} \mathrm{C}\right)$, and in the $28 \mathrm{~m}$ tree system at $2 \mathrm{~h} 47 \mathrm{p} . \mathrm{m} .\left(33.1^{\circ} \mathrm{C}\right)$. The maximum point in the systems without and with shade of $18 \mathrm{~m} 28 \mathrm{~m}$ occurred about an hour earlier than in the $8 \mathrm{~m}$ tree system This difference in time from the point of maximum air temperature in the $8 \mathrm{~m}$ tree system and $18 \mathrm{~m}$ and $28 \mathrm{~m}$ tree systemcan be related

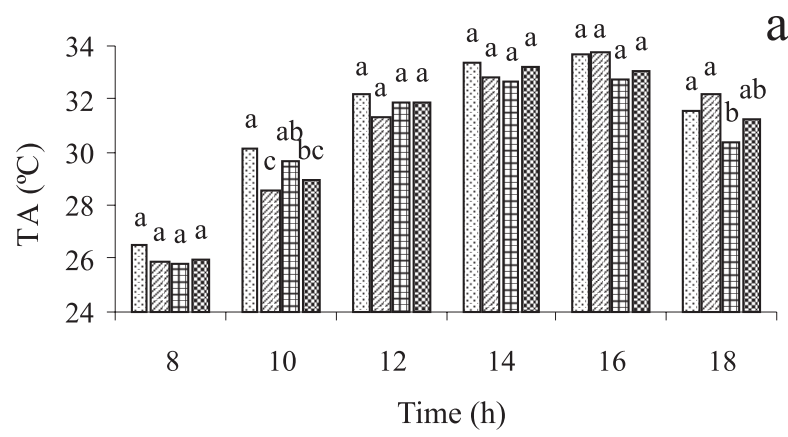

No shade $₫ 8 \mathrm{~m}$ trees $\boxplus 18 \mathrm{~m}$ trees $028 \mathrm{~m}$ trees

b

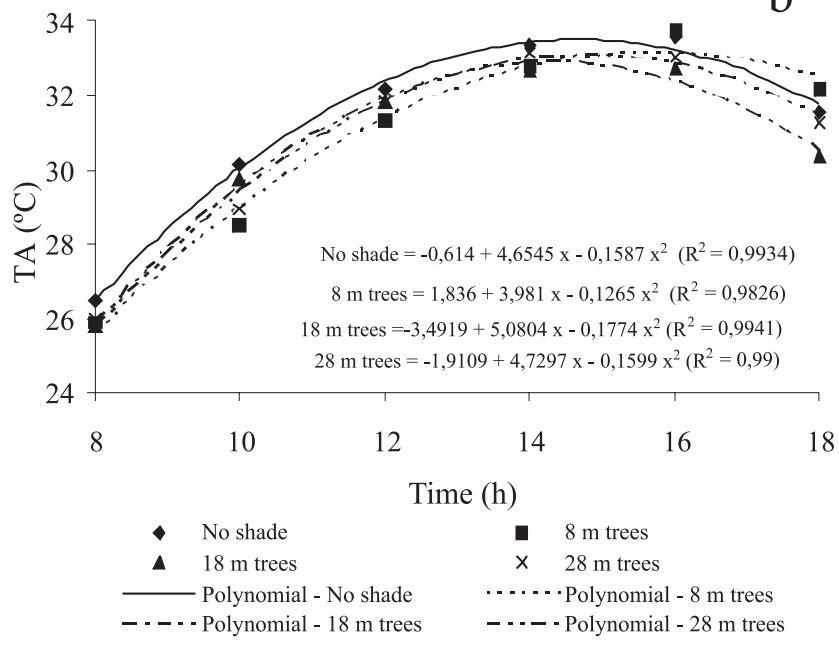

Figure 1 - Variation of air temperature (TA) systems as a function of time (hours). In groups of hours (a), columns with different letters differ $(\mathrm{P}<0.05)$ by Tukey test. to higher wind speeds in the $8 \mathrm{~m}$ tree system (Figure 4), which increased the movement of air masses, refreshing the environment and delaying the point of maximum air temperature. The difference in time from the point of maximum air temperature among the $8 \mathrm{~m}$ tree system and without shade may be related to the presence of shade trees in the system of $8 \mathrm{~m}$, therefore, the smaller area of soil exposed to solar radiation, the longer theenvironment takes to warm up and get to the point of maximum. The average air temperature of $30.8^{\circ} \mathrm{C}$ for the systems was similar to that found in the same region and period by Marques et al. (2005), that observed an average of $30.6^{\circ} \mathrm{C}$.

The black globe temperature indicated interaction time $\times$ system (Figure 2 ) and was lower for all the hours $(\mathrm{P}<0.05)$ in systems with trees, except for 12 p.m., when the $18 \mathrm{~m}$ tree system $\left(37.9^{\circ} \mathrm{C}\right)$ did not differ from that without shade $\left(40^{\circ} \mathrm{C}\right)$. The black globe temperature at $12 \mathrm{p} . \mathrm{m}$. in the $8 \mathrm{~m}$ tree , $18 \mathrm{~m}$ tree, and in the $28 \mathrm{~m}$ tree systems $\left(36.9^{\circ} \mathrm{C}, 37.9^{\circ} \mathrm{C}\right.$ and $36.5^{\circ} \mathrm{C}$ ) and at $2 \mathrm{p} . \mathrm{m} .\left(39.1^{\circ} \mathrm{C}, 39.0^{\circ} \mathrm{C}\right.$ and $\left.38.0^{\circ} \mathrm{C}\right)$ did not differ $(\mathrm{P}>0.05)$, but were lower $(\mathrm{P}<0.05)$ than the system

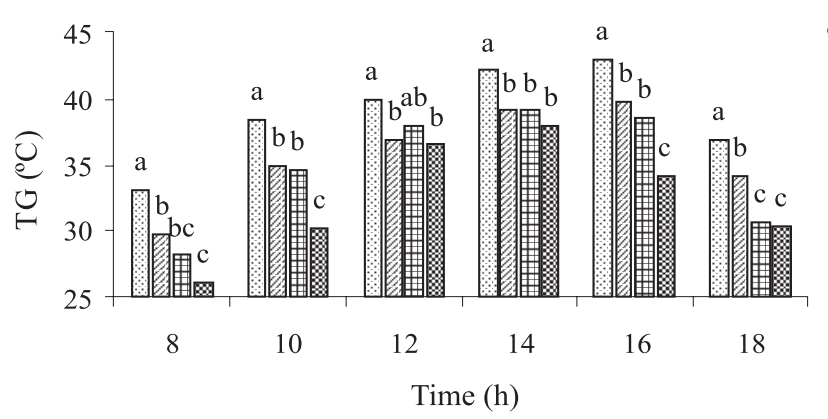

a

No shade $8 \mathrm{~m}$ trees 团 $18 \mathrm{~m}$ trees $28 \mathrm{~m}$ trees

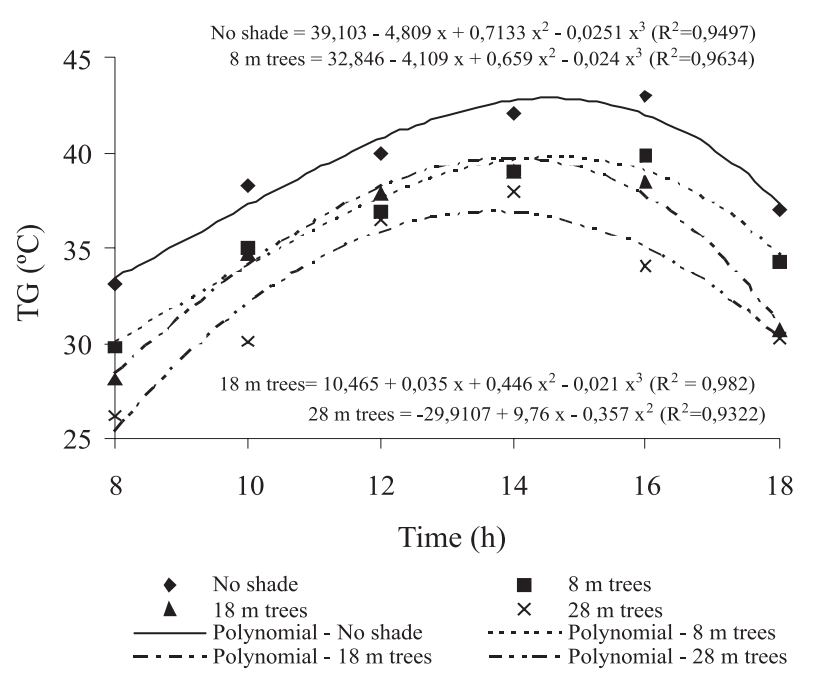

b

Figure 2 - Variation of the black globe temperature (TG) systems at various times (hours). In groups of hours, columns with different letters differ $(\mathrm{P}<0.05)$ by Tukey test. 
without shade at 12 p.m. $\left(40.0^{\circ} \mathrm{C}\right)$ and 2 p.m. $\left(42.1^{\circ} \mathrm{C}\right)$. On $8 \mathrm{~m}$ and $18 \mathrm{~m}$ tree systems, temperatures at 10 a.m. $\left(35.0^{\circ} \mathrm{C}\right.$ and $\left.34.7^{\circ} \mathrm{C}\right)$ and at $4 \mathrm{p} . \mathrm{m} .\left(39.9^{\circ} \mathrm{C}\right.$ and $\left.38.5^{\circ} \mathrm{C}\right)$ were similar $(\mathrm{P}<0.05)$ and greater than system with trees from $28 \mathrm{~m}$ to 10 $\mathrm{m}\left(30.1^{\circ} \mathrm{C}\right)$ and at 4 p.m. $\left(34.1^{\circ} \mathrm{C}\right)$ in respective times and smaller than the system without shade for 10 a.m. $\left(38.3^{\circ} \mathrm{C}\right)$ and 4 p.m. $\left(43.0^{\circ} \mathrm{C}\right)$. For systems with trees of 18 and $28 \mathrm{~m}$, respectively, at 8 a.m. $\left(28.1^{\circ} \mathrm{C}\right.$ and $\left.26.2^{\circ} \mathrm{C}\right)$ and at 6 p.m. $\left(30.7^{\circ} \mathrm{C}\right.$ and $\left.30.3^{\circ} \mathrm{C}\right)$, there were no differences $(\mathrm{P}>0.05)$, but temperatures were lower $(\mathrm{P}<0.05)$ than to the system with $8 \mathrm{~m}$ to $18 \mathrm{~m}$ trees $\left(34.3^{\circ} \mathrm{C}\right)$; however at 8 a.m. system with 18 $\mathrm{m}$ trees did not differ from that of the $8 \mathrm{~m}$ trees $\left(29.8^{\circ} \mathrm{C}\right)$, confirming the effect of tree height. The minimum, mean and maximum global temperature in different systems were $20.0^{\circ} \mathrm{C}, 35.5^{\circ} \mathrm{C}$ and $54.0^{\circ} \mathrm{C}$, respectively, similar to those found in the same region and time of year by Barbosa et al. (2001) that observed minimum, mean and maximum globe temperature of $21.6^{\circ} \mathrm{C}, 34.0^{\circ} \mathrm{C}$ and $56^{\circ} \mathrm{C}$.

The regressions of time on the black globe temperature (Figure 2) indicated a quadratic effect for the $28 \mathrm{~m}$ tree system and cubic effect for the other systems $(\mathrm{P}<0.05)$. The point of maximum estimated by the quadratic equation for the $28 \mathrm{~m}$ tree system occurred at 1:41 p.m. $\left(36.9^{\circ} \mathrm{C}\right)$. In the range from 8 a.m. to 6 p.m., the point of maximum estimated by cubic equations for systems without shade and 8 and 18 m tree system occurred ,respectively, at 2:36 p.m. $\left(42.9^{\circ} \mathrm{C}\right)$, 2:37 p.m. $\left(39.8^{\circ} \mathrm{C}\right) 1: 57$ p.m. $\left(39.7^{\circ} \mathrm{C}\right)$ and in this interval, there was no point for the minimum cubic equations. The behavior of the globe temperature concerning to hours occurred in proportion to the 18 and $28 \mathrm{~m}$ tree systems, while the $8 \mathrm{~m}$ tree system it was proportional to the system without shade throughout the day in which, after the maximum point, the drop in globe temperature was less marked than in 18 and $28 \mathrm{~m}$ tree systems.

Thermal comfort of the animals of many species depends very much on the levels of atmospheric humidity in combination with temperature. Thus, in very hot environments, excess and lack of humidity are harmful. In warm and very dry environment, evaporation is very fast and cause irritation and dehydration; generally, in a warm and too humid environment, the evaporation becomes very slow or zero, reducing thermolysis (Silva, 2000). In general, in a tropical environment, the physical mechanism of thermolysis is the most efficient evaporative and do not depend on the temperature differential between the body and the atmosphere.

In general, the observed daily averages of relative humidity (Figure 3) are in the range of comfort proposed by Leal \& Nããs (1992) and this is desirable, because in the peak hours (from 12 p.m. to 4 p.m.) the average relative humidity in the systems ranged from $60.3 \%$ to $46.3 \%$, contributing to the loss of heat by evaporative processes, one of the key features of endothermic regulation at high temperatures. According to Hafez (1973), the increase of the relative humidity decreases the heat dissipation through the skin loss in the diffusion of water.

The average relative humidity did not differ $(\mathrm{P}>0.05)$ among systems without shade and 8 and $28 \mathrm{~m}$ tree systems (Figure 3 ) and it was 54.9\%, 55.6\% and 55.0\% respectively, but lower $(\mathrm{P}<0.05)$ than the $18 \mathrm{~m}$ tree system $(62.4 \%)$. The biggest difference $(\mathrm{P}<0.05)$ of the relative humidity in the $18 \mathrm{~m}$ tree system compared to other systems is not related to tree height, but to the local environment, since environmental factors alter the microclimate as result of slopes and water sources.

The regressions of time on the relative humidity (Figure $3 b$ ) showed a quadratic effect $(\mathrm{P}<0.05)$, reaching a minimum relative humidity estimated by the quadratic equation at 3:18 p.m., with 49.70\%.

The underlying cause of air movement in a horizontal direction of the wind is the existence of a gradient of atmospheric pressure, which acts as a force moving the air from areas of high to low pressure. The air is a fluid with a
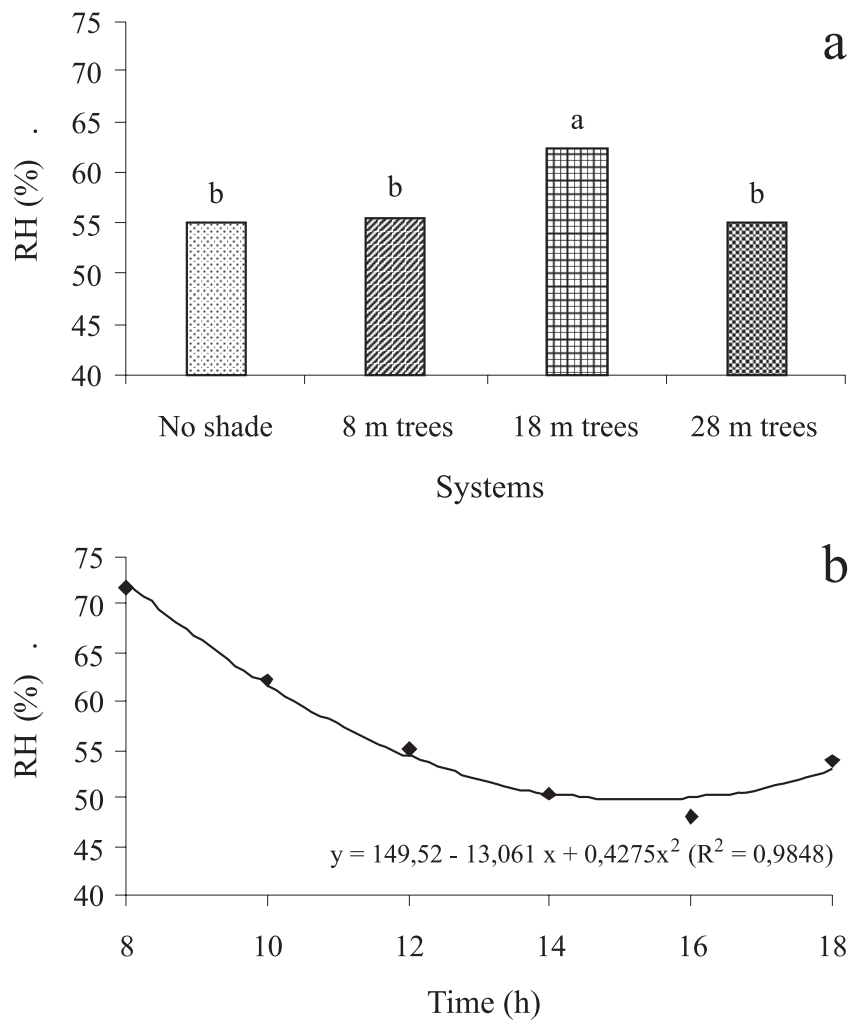

Figure 3 - Relative humidity (RH) in silvopastoral systems (a). Treatments with different letters differ $(\mathrm{P}<0.05)$ by Tukey test. Relative humidity as a function of time (hours) of day (b). 
certain degree of viscosity, which varies with the temperature and enough for the wind suffer some drag force. Roughness, rocky or covered with vegetation "grab" the air, therefore, near the surface, the wind speed is considerably reduced. If the animals are outdoors, the hair coat thermal resistance decreases as the wind speed increases and, forced convection can ,then, become more important for heat transfer through the hood, depending on the speed and direction of the wind regarded to the body of the animal (Silva, 2000).

Windbreaks of Grevillea robusta cause reduction in wind speed in a range that exceeds two times the height of the rank to windward and 16 times the height of the swath downwind (Durigan \& Simões, 1987).

The wind speed showed interaction time $\times$ system (Figure 4). The wind speed on $18 \mathrm{~m} 28 \mathrm{~m}$ tree systems was similar $(\mathrm{P}>0.05)$ at all times. The $28 \mathrm{~m}$ tree system, except 6 p.m., decreased the wind speed at all times, while in the $8 \mathrm{~m}$ tree system the only possible reduction of wind speed occured at a.m. and was similar to the system without shade at other times.

At times of highest wind speed, on systems with trees, the greatest reduction of wind speed occurred; however, this reduction was not proportional to tree height of each
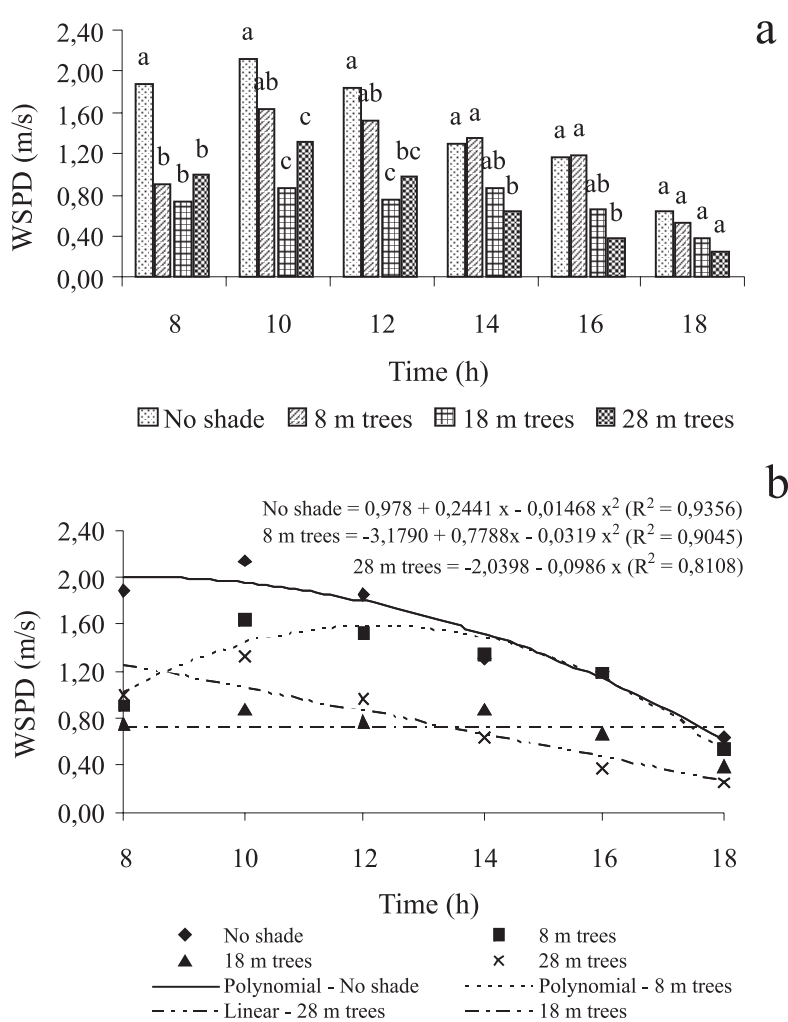

Figure 4 - Wind speed (WSPD) in the systems as a function of time (hours). In groups of hours (a), columns with different letters differ $(\mathrm{P}<0.05)$ by Tukey test. system. At 10 a.m., hour of the highest mean wind speed in the system without shade, the wind speed was similar to the $8 \mathrm{~m}$ tree system, higher than in other systems $(\mathrm{P}<0.05)$. At 12 p.m., the $28 \mathrm{~m}$ tree system, the highest point gave similar reduction $(\mathrm{P}>0.05)$ to that observed in the $8 \mathrm{~m}$ tree system, the lowest point, and in the $18 \mathrm{~m}$ tree system, high intermediate, the values were in agreement with the results found by Schöffel \& Volpe (2005), who worked with ranks of polypropylene with $82 \%, 70 \%, 50 \%$ and $30 \%$ of porosity and observed that the reduction in wind speed is increased by a barrier with speed, but concomitant with this, it increases the variability of this reduction. Similarly, when the measurements are made with ranks of trees, the reduction depends on the wind speed. However, to ranks of leafy trees, the leaves tend to be in parallel to the wind flow in which the porosity increases with speed, which causes a smaller reduction of wind speed. However, for ranks consisting of conifers, the branches tend to plate against each other when the wind speed increases, the porosity decreases and then wind reduction is stronger (Guyot, 1989). However, the height of the trees may also influence the reduction of wind speed, because when wind speed is higher the reduction can be decreased by increasing the height of the crown.

The regressions for the time on wind speeds (Figure 4) indicated a quadratic effect $(\mathrm{P}<0.05)$ for systems with and without and $8 \mathrm{~m}$ tree system and a linear effect $(\mathrm{P}<0.05)$ for the system with trees $28 \mathrm{~m}$ trees. The point of maximum wind speed estimated by the quadratic equations for systems with and without shade and $8 \mathrm{~m}$ tree system occurred, respectively, at 8:19a.m. (1.99 m/s) and at 12:12 p.m. (1.57 m/s). There was no effect regression $(\mathrm{P}>0.05)$ for the $18 \mathrm{~m}$ tree system. The effect of wind on heat exchange of animals through the coat depends on the density of the coat, because if it is too thick, it hinders the penetration of air and heat is transfered by convection. When the wind speed is low (less than $1 \mathrm{~m} / \mathrm{s}$ ), this effect is not significant, especially in dense hair coat. The wind effect is higher when the animal is reached in the direction against the hair, which is desirable in warm climates (Silva, 2000).

Compared to the average of the system without shade, in $8 \mathrm{~m}$ tree, $18 \mathrm{~m}$, and $28 \mathrm{~m}$ tree systems, the wind speed decreased 20.7, 50.0 and 48.0\% respectively. The difference between reduction of wind speed and height of ranks may also have been influenced by the difference among the porosity and height of the crown, since the $28 \mathrm{~m}$ tree system with maximum height of the crown allowed greater speed wind near the ground, compared to that of $18 \mathrm{~m}$ tree, so a lower height of the crown. Durigan \& Simões (1987) considering the rank porosity concluded that the point of 
maximum protection in a more compact rank occurs to a distance of two times their height and to a less compact rank occurs to a distance of four times their height. Therefore, considering the height of the ranks, the $8 \mathrm{~m}$ tree, $18 \mathrm{~m}$ tree and $28 \mathrm{~m}$ tree systems would have a shield, respectively, from $16 \mathrm{~m}$ to $32 \mathrm{~m}, 36 \mathrm{~m}$ to $72 \mathrm{~m}$ and $50 \mathrm{~m}$ to $100 \mathrm{~m}$. Since the distance between ranks was $25 \mathrm{~m}$, the $8 \mathrm{~m}$ tree system was less efficient, due to the height of the rank and it can be fitted in with the other when the height of the rank is $12.5 \mathrm{~m}$.

The temperature-humidity index (Figure 5) showed a time $\times$ system interaction $(\mathrm{P}<0.05)$. At 10 a.m., with the same behavior of air temperature, the temperature-humidity index in the systems without shade and systems with $18 \mathrm{~m}$ trees of 80.4 and 80.5 were similar to $(\mathrm{P}>0.05)$ and with value greater than to the systems with trees $8 \mathrm{~m} 28 \mathrm{~m}$ with 78.5 and 78.9 and did not differ $(\mathrm{P}>0.05)$. At 12 p.m., the temperature-humidity index in the $18 \mathrm{~m}$ tree system, where the relative humidity was higher $(\mathrm{P}<0.05)$ the highest value $(82.8)(\mathrm{P}<0.05)$ was also presented compared to the $8 \mathrm{~m}$ tree system $(81.5)$ and similar to $(\mathrm{P}>0.05)$ systems

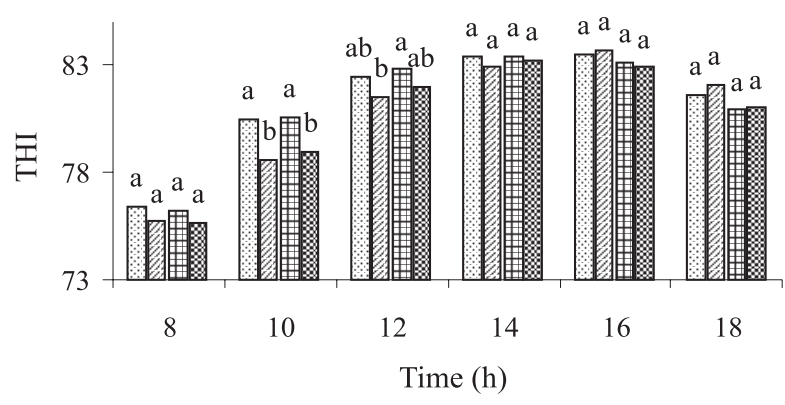

No shade $⿴ 囗 0 \mathrm{~m}$ trees $⿴ 18 \mathrm{~m}$ trees $028 \mathrm{~m}$ trees

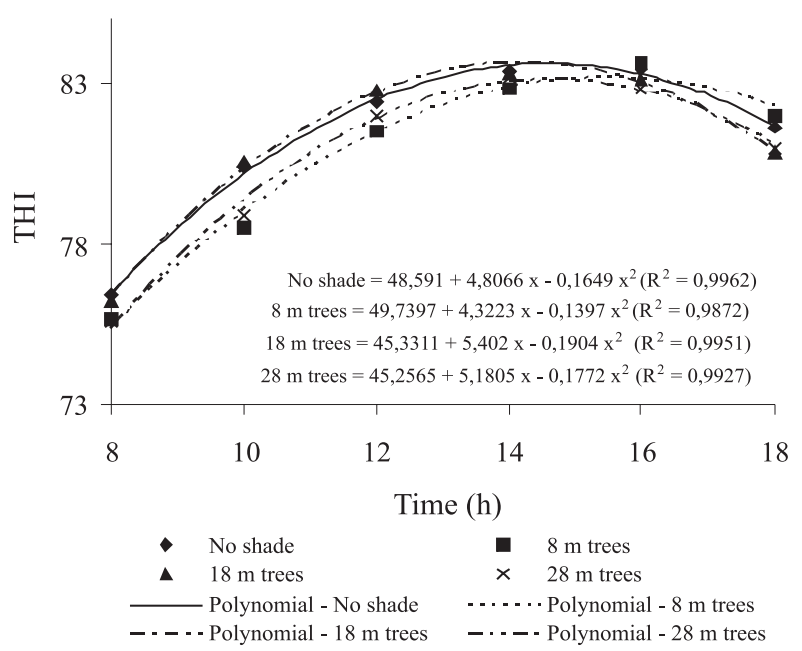

Figure 5 - Temperature-humidity index (THI) systems as a function of time (hours). In groups of hours, columns with different letters differ $(\mathrm{P}<0.05)$ by Tukey test. without shade (82.4) and $28 \mathrm{~m}$ trees (82) (Figure 5). This result at 12 p.m. was influenced by the relative humidity weight of the composition of the temperature-humidity index. At the other hours, there were no differences $(\mathrm{P}>0.05)$ for temperature-humidity indices in environments with trees compared to the system without shade, confirming observations by Buffington et al. (1981) that this index does not represent the reality of climatic conditions in regions with high levels of radiation. According to Hahn (1985), cited by Silva (2000), value of temperature-humidity index of 70 or less indicates normal condition, not stressing; value between 71 and 78 is critical, between 79 and 83 indicates danger; above 83 is an emergency. According to these authors, these tracks would be valid for animals in general, not just dairy cattle.

Bohmanova et al. (2007) evaluated seven temperaturehumidity indices with different weights between the dry bulb temperature and wet bulb in two environments, in a semi-arid climate and other moist, and concluded that the indices with higher weights of humidity were the best in wet weather, because indices with greater weight in temperature were the best indicators of heat stress in the semiarid climate. Humidity was the limiting factor of heat stress in humid climates, as the dry bulb temperature was the limiting factor of heat stress in dry climates.

The temperature-humidity index using the intensity of heat at a given time do not consider the time of exposure of animals to adverse thermal conditions of the environment neither in the day nor the night and the day after, because heat stress can be mitigated or sharpen (Gaughan et al., 2008).

The regressions on the time temperature-humidity index (Figure 5) indicated a quadratic effect $(\mathrm{P}<0.05)$ for all systems. The point of maximum temperature-humidity index estimated by the quadratic equation for systems with and without shade trees of $8 \mathrm{~m}, 18 \mathrm{~m}$ and $28 \mathrm{~m}$, respectively, occurred at 2:34 p.m., with 83.6, 3:28 p.m., with 83.2; 14:11 with 83.6 and 2:37 p.m. hours, with 83.1 , hours similar to those obtained for air temperature.

For the black globe-humidity index, there was a system $\times$ time interaction $(\mathrm{P}<0.05)$ (Figure 6$)$. The presence of trees provided a reduction of average temperature index globehumidity during the hottest hours of the day compared to non-shaded environment, which is good, mainly because the means were analyzed without considering the extreme events. Systems with $8 \mathrm{~m}$ and $18 \mathrm{~m}$ to $28 \mathrm{~m}$ trees presented mean black globe-humidity index (Figure 6) decreased $(\mathrm{P}<0.05)$ than to the observed in the system without shade at all times, except system with trees of $18 \mathrm{~m}$, which at $12 \mathrm{p} . \mathrm{m}$. and 2 p.m. did not differ from the system without shade, confirming that the black globe-humidity index best 
represents the reality of climatic conditions in regions with higher rates of solar radiation (Buffington et al., 1981).

The regressions of time on the mean black globehumidity index (Figure 6) indicate a quadratic effect $(\mathrm{P}<0.05)$ for all systems. The point of maximum black globe-humidity index estimated by quadratic equations for systems without shade and with $8 \mathrm{~m}, 18 \mathrm{~m}$ and $28 \mathrm{~m}$ tree system occurred respectively at 1:55 p.m. with 90.4, at 2:01 p.m., with 89.3, 1:26 p.m., with 90.2 , and at 1:40 p.m., with 87 . Similar results were observed by Barbosa et al. (2004) in the same region and time of year. These authors found maximum black globehumidity index in the afternoon sun in the 95 and shade 88.

In different systems, there was time $\times$ system interaction $(\mathrm{P}<0.05)$ for the heat load index (Figure 7), which, in systems with shade, improved the condition of heat stress $(\mathrm{P}<0.05)$ for all times, except $8 \mathrm{~m}$ tree system at 8 a.m. and 6 p.m., 18 $\mathrm{m}$ tree system at $12 \mathrm{p} . \mathrm{m}$. and 2 p.m., and $28 \mathrm{~m}$ tree system at 12 p.m., which were similar $(\mathrm{P}>0.05)$ to the systems without shade. The $28 \mathrm{~m}$ tree system at 10 a.m. and 4 p.m. led to higher

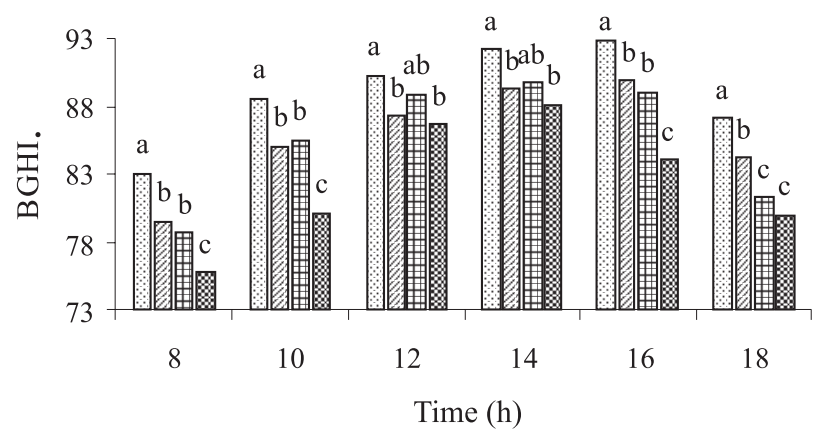

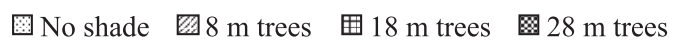

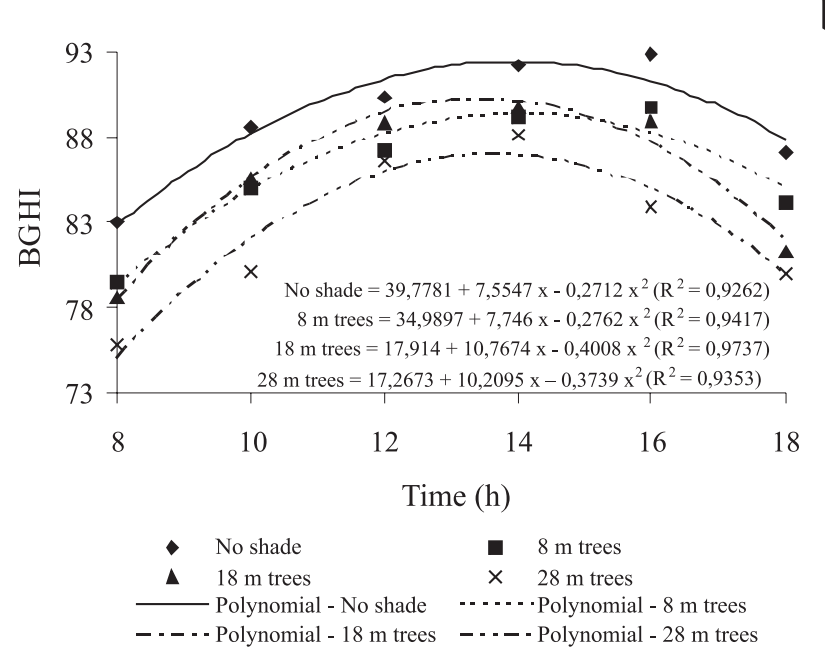

Figure 6 - Black globe-humidity index (BGHI) systems as a function of time (hours). In groups of hours (a), columns with different letters differ $(\mathrm{P}<0.05)$ by Tukey test.
$(\mathrm{P}<0.05)$ reductions in the heat load index on the order of 9 points, in the the system without shade.

The regressions of time on the mean heat load index (Figure 7 ) show a quadratic effect $(\mathrm{P}<0.05)$ for all systems. The point of maximum heat load index estimated by the quadratic equations for systems without shade and $8 \mathrm{~m}, 18 \mathrm{~m}$ and $28 \mathrm{~m}$ tree systems, occurred respectively at 2:22 p.m., with 83.4 , at 2.33 p.m. with 79.7 ; at 1:42 p.m., with 80.5 , and at 1:59 p.m., with 78.3.

Silva et al. (2007) evaluated the correlation of thermal comfort indices in rectal temperature and respiration rate in dairy cattle in tropical climate and concluded that the temperature-humidity index and black globe-humidity index were not correlated with the physiological responses in a tropical environment, therefore, it should not be used in this environment to specity of thermal stress of dairy cattle. The heat load index had significant correlation of 0.286 with the rectal temperature and 0.542 with the respiratory rate and can be considered the best index to
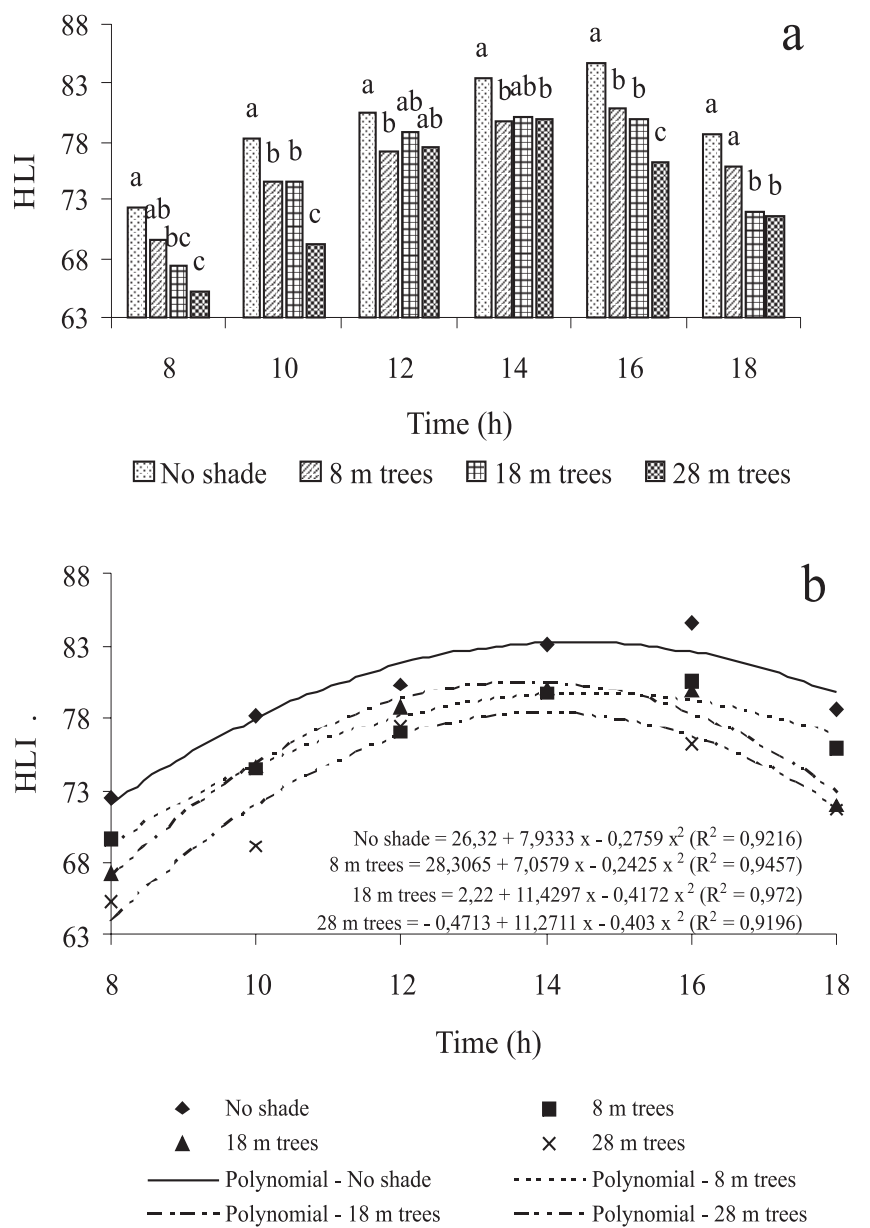

Figure 7 - Heat load index (HLI) systems as a function of time (hours). In groups of hours, columns with different letters differ $(\mathrm{P}<0.05)$ by Tukey test. 
assess tropical environments for dairy cattle. In tropical regions, the value of heat load index equal to or less than 89 indicates normal condition, between 89 and 92 provided care, between 92 and 95 provided extreme care and more than 95 dangerous condition. In this paper, the values of heat load index at or above 89 for systems with and without shade $8 \mathrm{~m}$ tree, $18 \mathrm{~m}$ and to $28 \mathrm{~m}$ tree system were respectively $53.7 \%$, $14.8 \%, 25.9 \%$ and $5.6 \%$, proving to be effective for systems with shade; however, this effect was not proportional to the height of ranks, as the wind speed is a reductive effect, contrary to the relative humidity and temperature of the globe in the composition of this index.

There was a time $\times$ system interaction $(\mathrm{P}<0.05)$ for the radiant thermal load index (Figure 8 ) which, in the system without shade, was higher $(\mathrm{P}<0.05)$ than for the other systems at all the hours and, from 10 a.m. to 4 p.m., it showed little variation, while in the systems with trees the radiant heat load was proportional inversely to the increase in height of the ranks (Figure 8).

Systems with $8 \mathrm{~m}, 18 \mathrm{~m}$ and $28 \mathrm{~m}$ tree did not differ at 12 p.m. Systems with $8 \mathrm{~m} 18 \mathrm{~m}$ trees did not differ at all times, at 8 a.m. and 18 a.m., the system with $18 \mathrm{~m}$ trees did not differ from that with $28 \mathrm{~m}$ trees, with the lowest average radiant


Figure 8 - Radiant thermal load (RTL) in silvopastoral systems without shade and with trees of $8 \mathrm{~m}, 18 \mathrm{~m}$ or $28 \mathrm{~m}$ at various times (hours). In groups of hours, columns with different letters differ $(\mathrm{P}<0.05)$ by Tukey test. thermal load in relation to other systems at 10 a.m., 2 p.m. and 4p.m.

The regressions of time on the average radiant thermal load (Figure 8) indicated a quadratic effect $(\mathrm{P}<0.05)$ for all systems. The point of maximum radiant thermal load estimated by the quadratic equations for systems without shade and with $8 \mathrm{~m}, 18 \mathrm{~m}$ and $28 \mathrm{~m}$ trees occurred, respectively, at 12:47 p.m. with 709.9; 1:07 p.m., with 637.2; 1:02 p.m., with 621.2 , and 1:10 p.m., with $562.5 \mathrm{~W} / \mathrm{m}^{2}$. The reduction in the radiant thermal load in the systems with $8 \mathrm{~m}$ tree, $18 \mathrm{~m}$ and $28 \mathrm{~m}$ tree systems, with the system without shade at the point of maximum was $10.24 \%, 12.49 \%$ and 20.76\%, in agreement with Baccari Jr. (2001) and Turco (1993), who observed reduction of the radiant thermal compared to a non-shaded area.

\section{Conclusions}

The presence of trees does not change the relative humidity and air temperature,except for air temperature at 10 a.m and 6 p.m., but it affects the globe temperature and wind speed, showing effect of the height of ranks in different hours of the day. The index of black globe-humidity and radiant heat load, which consider estimating solar radiation, indicate that the presence of trees improves the environment and comfort to animals, and it is also proportional to the height of ranks in times of higher solar radiation. The temperature-humidity index is changed only by the presence of trees at 10 a.m. and 12 p.m., considering the composition of air temperature with the highest weight. The presence of trees improves the environmental conditions, but this improvement is not proportional to the height of ranks, so it is more efficient to evaluate the thermal comfort.

\section{References}

BACCARI JR., F. Manejo ambiental da vaca leiteira em climas quentes. Londrina: Universidade Estadual de Londrina, 2001. 142p.

BARBOSA, O.R.; MACEDO, F.A.F.; MARTINS, E. N. et al. Zoneamento bioclimático da ovinocultura no Estado do Paraná. Revista Brasileira de Zootecnia, v.30, p.597-603, 2001.

BARBOSA, O.R.; BOZA, P.R.; SANTOS, G.T. et al. Efeitos da sombra e da aspersão de água na produção de leite de vacas da raça Holandesa durante o verão, Acta Scientiarum Animal Sciences, v.26, n.1, p.115-122, 2004.

BARBOSA, O.R.; SILVA, R.G. Índice de conforto térmico para ovinos. Revista Brasileira de Zootecnia, v.24, n.6, p.874-883, 1995.

BOHMANOVA, J.; MISZTAL, I.; COLE, J.B.J. Temperaturehumidity indexes as indicators of milk production losses due to heat stress. Dairy Science, v.90, p.1947-1956, 2007.

BUFFINGTON, D.E.; COLLAZO-AROCHO, A.; CANTON, G.H. et al. Black globe-humidity index (BGHI) as confort equation for dairy cows. Transactions of the American Society of Agricultural Engineers, v.24, p.711-714, 1981. 
DETZEL, V.A. Arborização Urbana: importância e avaliação econômica. In: CONGRESSO BRASILEIRO SOBRE ARBORIZAÇÃO URBANA, 1., 1992, Vitória. Anais... Vitória: 1992. p.39-52.

DURIGAN, G.; SIMÕES J.W. Quebra-ventos de Grevillea robusta A. CUNN - Efeitos sobre a velocidade do vento, umidade do solo e produção do café. IPEF - Instituto de Pesquisas e Estudos Florestais, n.36, p.27-34, 1987.

ESMAY, M.L. Principles of animal environment. West Port: C.T. Avi Publishing, 1979. 325p.

FERREIRA, D.F. Análises estatísticas por meio do Sisvar para Windows versão 4.0. In: REUNIÃO ANUAL DA REGIÃO BRASILEIRA DA SOCIEDADE INTERNACIONAL DE BIOMETRIA, 45., São Carlos. Anais... São Carlos: UFSCarlos, 2000. p.255-258.

GAUGHAN, J.B.; MADER, T.L.; HOLT M. et al. A new heat load index for feedlot cattle. Journal of Animal Science, v.86, p.226-234, 2008 .

GAUGHAN, J.G.; GOOPY, J.; SPARK, J. Excessive heat load index for feedlot cattle. Sydney: MLA, 2002. (Meat and Livestock-Australia Project Report, 316). [mimeo.].

GUYOT, G. Les effets aerodynamiques et microchmatiques des brisevent et des amenagements regionaux. In: INTERNATIONAL COUNCIL FOR RESEARCH IN AGROFORESTRY, 1989, Nairobi, Kenya. Anais... Nairobi, 1989. p.485-520.

HAFEZ, E.S.E. Adaptacion de los animales domésticos. Barcelona: Labor, 1973. 563p.

HAHN, G.L. Management and housing of farm animals in hot environments. In: YOUSEF, M.K. (Ed.) Stress physiology in livestock. Boca Raton: CRC Press, 1985. v.2. p.151-176.

INSTITUTO AGRONÔMICO DO ESTADO DO PARANÁ - IAPAR. Cartas climáticas do Estado do Paraná. Londrina: IAPAR, 1994. 49p. (Documento, 18).

LEAL, P.M.; NÃ̃̃S, I.A. Ambiência animal. In: CORTEZ, L.A.B.; MAGALHÃES, P.S.G. (Orgs.). Introdução à engenharia agrícola. Campinas: Unicamp, 1992. p.121-135.

MARQUES, J.A.; BARBOSA, O.R.; ALBUQUERQUE, K.P. et al. Comportamento de novilhas bubalinas terminadas em confinamento usando promotor de crescimento ou esferas de chumbo no útero. Acta Scientiarum Animal Sciences, v.27, n.3, p.363-370, 2005
MENARIM FILHO, A. Produção e composição química de forragens em sitemas silvipastoris com Eucalyptus spp. 78f. 2007. Dissertação (Mestrado em Agronomia) - Universidade Estadual de Maringá, Maringá.

MOURA, D.J.; NÄÄS, I.A. Estudo comparativo de índices de conforto térmico na produção animal. In: CONGRESSO BRASILEIRO DE ENGENHARIA AGRÍCOLA, 1993, Lavras. Anais... Lavras, 1993. p.42-46.

PARRIS, R. Softwares Peanut:Winplot. Disponível em: <http:// math.exeter.edu/rparris/winplot.html>. Acesso em: 20/5/2008.

SAMPAIO, C.A.P.; CRISTANI, J.; DUBIELA, J.A. et al. Avaliação do ambiente térmico em instalação para crescimento e terminação de suínos utilizando os índices de conforto térmico nas condições tropicais. Ciência Rural, v.34, n.3, p.785-790, 2004.

SCHÖFFEL, E.R.; VOLPE, C.A. Redução relativa do vento com quebra-ventos de diferentes porosidades. Revista Brasileira de Agrometeorologia, v.13, n.2, p.284-291, 2005.

SILVA, I.J.O.; SILVA, K.O.; NÄÄS, I.A. Arborização: uma metodologia para avaliação da qualidade de sombras por meio dos índices de conforto térmico. In: CONGRESSO BRASILEIRO DE BIOMETEOROLOGIA, 2., 1998, Goiânia. Anais... Goiânia, 1998. p.277-283.

SILVA, K.O.; SILVA, I.J.O.; GHELFI FILHO, H. et al. Caracterização da sombra de árvores, através de índices de conforto térmico, para a região de Lavras-MG. In: CONGRESSO BRASILEIRO DE ENGENHARIA AGRICOLA, 24., 1995, Viçosa, MG. Anais... Viçosa, MG: SBEA, 1995. p.131.

SILVA, R.G. Introdução à bioclimatologia animal. São Paulo: Nobel, 2000. 286p.

SILVA, R.G.; MORAIS, D.A.E.F.; GUILHERMINO, M.M. Evaluation of thermal stress indexes for dairy cows in tropical regions. Revista Brasileira de Zootecnia, v.36, n.4, p.1192-1198, 2007.

THOM, E.C. The discomfort index. Weatherwise, v.12, p.57-59, 1958.

TURCO, S.H.N. Modificações das condições ambientais de verão, em maternidade de suínos. 1993. 58f. Dissertação (Mestrado em Construções Rurais e Ambiência) - Universidade Federal de Viçosa, Viçosa, MG. 